\title{
PROBLEMATIKA KEBIJAKAN LINIERISASI DAN MUTASI GURU DI KABUPATEN JEMBER
}

\author{
Imron Fauzi \\ Institut Agama Islam Negeri Jember, Indonesia \\ E-mail: imronfauzi@iain-jember.ac.id
}

\begin{abstract}
Abstrak: Tulisan ini ingin melihat bagaimana implementasi Undang-Undang No. 14 tahun 2005, Permendiknas No. 16 tahun 2007, serta Permendikbud No. 46 Tahun 2016 yang menuntut setiap guru untuk menjadi tenaga profesional yang berkompetensi dan sesuai dengan kualifikasinya. Karena itu pula, kebijakan Pemerintah Kabupaten Jember yang melakukan mutasi guru hanya karena janji kampanye turut disorot dalam penelitian ini. Penelitian ini menggunakan kualitatif berupa studi descriptive dan explorative yang mengungkap fenomena riil yang terjadi di Kabupaten Jember dengan cara wawancara, observasi, serta kajian dokumen berupa informasi valid melalui media cetak dan elektronik. Hasil penelitian ini menemukan bahwa problematika mutasi guru yang dilakukan oleh Pemerintah Kabupaten Jember diantaranya: pertama, mutasi guru tidak didasarkan pada kebutuhan sekolah (bezetting); kedua, banyak Guru Tidak Tetap (GTT) yang dimutasi lebih jauh dari domisilinya; ketiga, adanya kesenjangan antara proses mutasi guru PNS dengan GTT; keempat, sulitnya adaptasi diantara para guru dengan peserta didik pada tempat mutasi barunya; kelima, realisasi pemberian Surat Penugasan (SP) GTT tidak terlaksana sesuai dengan rencana awal; keenam, adanya kesalahan data mutasi guru dan penentuan tugas mengajar.
\end{abstract}

Kata Kunci: Implementasi Kebijakan, Linierisasi, Mutasi Guru

\section{Pendahuluan}

Problematika peningkatan kompetensi dan kinerja guru bukanlah masalah yang sederhana, melainkan merupakan permasalahan kompleks karena melibatkan banyak unsur yang saling terkait (interrelation), saling mempengaruhi (interaction), dan saling ketergantungan (interdepence) satu dengan yang lainnya. Sejatinya, kinerja guru akan sangat memberi dampak kepada mutu peserta didik baik dalam akademik, moral dan keterampilan. Sedangkan pada kenyataannya, manajemen guru belum banyak dikenal dan belum diterapkan dengan baik di setiap lembaga pendidikan. Hal ini didasarkan atas fakta bahwa jika individu dapat memuaskan kebutuhannya dengan mencapai apa yang menjadi tujuannya, dan pada saat yang sama memberi kontribusi bagi upaya organisasai meraih tujuan, maka individu tersebut besar kemungkinan memiliki motivasi dan mencapai kepuasan yang lebih tinggi, sedangkan ukuran kinerja guru terlihat dari rasa tanggung jawabnya menjalankan amanah, profesi yang diembannya, 
tanggung jawab moral dipundaknya, semua itu akan terlihat kepada kepatuhannya dan loyalitas di dalam menjalankan tugas keguruannya. ${ }^{1}$

Sejak 2005, guru-guru telah diseleksi untuk mengikuti program sertifikasi guru berdasarkan kualifikasi akademik, senioritas, dan golongan kepangkatan, seperti harus berpendidikan S-1 dan jumlah jam mengajar 24 jam per minggu. Indikator ini digunakan untuk memperhatikan kompetensi mereka. Data dari Kemendikbud merilis hingga 2016, terdapat 3.984.042 guru se-Indonesia dan sekitar 9.650 guru di Kabupaten Jember yang telah disertifikasi, baik melalui penilaian portofolio dan pelatihan yang telah diperoleh melalui PLPG maupun melalui PPG. ${ }^{2}$ Meskipun guru yang sudah memiliki kualifikasi S1 dan sertifikasi semakin meningkat, namun hingga saat ini masih sulit dilihat korelasi antara kualifikasi dan sertifikasi tersebut dengan peningkatan kualitas guru.

Hasil survei yang dilakukan Persatuan Guru Republik Indonesia (PGRI) mengenai dampak sertifikasi profesi guru terhadap kinerja guru. Dengan melakukan survey terhadap 16 dari 28 provinsi yang diteliti. Hasilnya sudah menunjukkan jika kinerja guru yang sudah disertifikasi belum meningkat secara signifikan. Guru-guru yang sudah lolos sertifikasi umumnya tidak menunjukkan kemajuan, baik dari sisi pedagogis, kepribadian, profesional, maupun sosial. Guru hanya aktif menjelang sertifikasi, tetapi setelah dinyatakan lolos, kualitas mereka justru semakin menurun. ${ }^{3}$

Problematika lain, masih banyak juga yang meragukan profesionalitas guru dengan alasan bahwa pekerjaan yang bersifat profesional hanya dapat dilakukan oleh mereka yang khusus dipersiapkan untuk itu, bukan seperti guru yang dapat dilakukan oleh mereka yang tidak dapat memperoleh perkerjan lain. Meskipun guru sudah diarahkan khusus kepada bidang pendidikan, tetapi pelaksanaannya belum terpadu sehingga belum memenuhi harapan dan tuntutan profesi, serta pengakuan dari masyarakat. Sampai saat ini, masih ada ganjalan yang melemahkan profesionalitas guru, di antaranya guru masih dianggap sebagai karier terbuka, sehingga siapa saja bisa menjadi guru asal memiliki pendidikan S-1 atau D-IV.

\footnotetext{
${ }^{1}$ Ahmad S. Ruky, Sistem Manajemen Kinerja (Jakarta: Gramedia Pustaka, 2002), 11.

2 http:/ / data.go.id/dataset/guru-sertifikasi, diakses pada 25 Oktober 2018.

${ }^{3}$ Haffid Abas, Kinerja Guru Bersertifikat Belum Memuaskan, dalam Kompas Edisi 6 Oktober 2010.

40 | Tarbiyatuna: Jurnal Pendidikan Islam; Volume 12, Nomor 1, Februari 2019 p-ISSN: 2085-6539, e-ISSN: 2242-4579
} 
Rendahnya pengakuan masyarakat terhadap profesi guru tersebut disebabkan oleh beberapa faktor, antara lain: pertama, adanya pandangan sebagian masyarakat bahwa siapapun dapat menjadi guru, asalkan ia memiliki pengetahuan; kedua, kekurangan guru di daerah tertentu memberikan peluang untuk mengangkat seseorang yang tidak mempunyai kewenangan profesional untuk menjadi guru; ketiga, banyak guru yang belum menghargai profesinya, apalagi berusaha mengembangkan profesi tersebut. Perasaan rendah diri karena menjadi guru, penyalahgunaan profesi untuk kepuasaan dan kepentingan pribadinya, dan lain-lain, yang dapat memudarkan wibawa guru dengan sendirinya menghambat mutu. ${ }^{4}$

Pasca pemberlakuan UU No. 14 tahun 2005 tentang Guru dan Dosen, program Akta IV secara bertahap dihapus. Setelah UU No. 14 tahun 2005 tentang Guru dan Dosen disahkan, semua calon guru wajib memiliki kualifikasi minimal Strata 1 (S-1) atau Diploma IV (D-4) dan untuk menjadi pendidik profesional harus lulus Program Pendidikan Profesi (PPG). Sebagaimana dalam PP No. 74 tahun 2008 tentang Guru Pasal 2 disebutkan, "Guru wajib memiliki kualifikasi akademik, kompetensi, sertifikat pendidik, sehat jasmani dan rohani, serta memiliki kemampuan untuk mewujudkan tujuan pendidikan nasional." Kemudian terkait dengan linieritas ijazah dengan tugas mengajar yang diampu secara lebih detail diatur melalui Permendiknas No. 16 tahun 2007 tentang Kualifikasi dan Kompetensi Guru yang di dalamnya dijelaskan kualifikasi guru pada semua jenjang pendidikan formal, mulai tingkat RA/TK hingga SMA/MA/SMK. Realita di lapangan, meskipun profesi guru sudah menjadi tenaga profesional sesuai amanat UU No. 14 tahun 2005 dan Permendiknas No. 16 tahun 2007, namun masih banyak juga permasalahan yang ditemukan terkait dengan linieritas guru.

Untuk menanggulangi problematika terkait linieritas guru tersebut, maka Pemerintah Kabupaten Jember menetapkan kebijakan tentang mutasi guru, baik guru PNS maupun Guru Tidak Tetap (GTT), khususnya pada guru di tingkat Sekolah Dasar (SD) dan Sekolah Menengah Pertama (SMP). Meskipun tujuan awal kebijakan tersebut adalah untuk me-linier-kan serta memberikan kepastian dan jaminan kepada

${ }^{4}$ E. Mulyasa, Menjadi Guru yang Profesional: Menciptakan Pembelajaran yang Kreatif dan Menyenangkan (Bandung: PT. Remaja Rosdakarya Offset, 2011), 10. 
para guru di Kabupaten Jember, namun hasil implementasi kebijakan mutasi guru tersebut masih menuai banyak kendala dan tantangan, sehingga membutuhkan sebuah alternatif solusi yang harus segera dilakukan. Oleh karena itu, makalah ini menjadi penting untuk dijadikan sebagai bahan kajian dan diskusi dalam rangka menemukan solusi yang terbaik demi kemajuan pendidikan, khususnya di Kabupaten Jember.

\section{Kebijakan Linierisasi Guru}

Kebijakan secara sederhana dapat diartikan, apa pun pilihan pemerintah untuk melakukan atau tidak melakukan (public policy is whatever governments choose to do or not to do). ${ }^{5}$ Definisi kebijakan tersebut mengandung makna bahwa, (1) kebijakan publik tersebut dibuat oleh badan pemerintah, bukan organisasi swasta; (2) kebijakan publik menyangkut pilihan yang harus dilakukan atau tidak dilakukan oleh badan pemerintah. Kebijakan pemerintah untuk tidak membuat program baru atau tetap pada status quo.

Keberhasilan kebijakan dapat dikaji berdasarkan perspektif proses implementasi dan perspektif hasil. Pada perspektif proses, program pemerintah dikatakan berhasil jika pelaksanaannya sesuai dengan petunjuk dan ketentuan pelaksanaan yang dibuat oleh pembuat program yang mencakup antara lain cara pelaksanaan, agen pelaksana, kelompok sasaran dan manfaat program. Sedangkan pada perspektif hasil, program dapat dinilai berhasil manakala program membawa dampak seperti yang diinginkan. Suatu program mungkin saja berhasil dilihat dari sudut proses, tetapi boleh jadi gagal ditinjau dari dampak yang dihasilkan, atau sebaliknya.

Di zaman persaingan seperti sekarang, profesionalisme menjadi satu-satunya cara untuk mengukur kualitas seorang guru. Karena itu, istilah atau status guru PNS, Guru Swasta, Guru Tetap, Guru Tidak Tetap, Guru Honorer, atau Guru Sukwan, tidak terlalu relevan dikaitkan dengan gagasan profesionalisme guru. Di banyak lembaga swasta yang besar dan maju, status pegawai tetap malah membuat lembaga pendidikan swasta tidak mampu mengembangkan gurunya secara profesional sebab 
mereka telah merasa mapan. Demikian juga yang menjadi pegawai negeri, banyak yang telah merasa nyaman sehingga lalai mengembangkan dirinya. Oleh karena itu, guru harus kembali pada jati dirinya yaitu memiliki standar kompetensi dan kualifikasi sebagaimana yang telah ditetapkan dalam UU No. 14 Tahun 2005 tentang Guru dan Dosen; PP No. 19 Tahun 2005 tentang Standar Nasional Pendidikan juncto PP No. 32 Tahun 2013; PP No. 74 Tahun 2008 tentang Guru juncto PP No. 19 tahun 2017, dan Permendiknas No. 16 Tahun 2007 tentang Kualifikasi dan Kompetensi Guru. ${ }^{6}$

Dalam PP No. 74 tahun 2008 tentang Guru jo PP No. 19 tahun 2017 Pasal 2 disebutkan, "Guru wajib memiliki kualifikasi akademik, kompetensi, sertifikat pendidik, sehat jasmani dan rohani, serta memiliki kemampuan untuk mewujudkan tujuan pendidikan nasional."7 Kompetensi guru ini meliputi kompetensi pedagogik, kompetensi kepribadian, kompetensi sosial, dan kompetensi profesional yang diperoleh melalui pendidikan profesi.

Meskipun profesi guru sudah menjadi tenaga profesional sesuai amanat UU No. 14 tahun 2005 dan Permendiknas No. 16 tahun 2007, namun masih banyak permasalahan yang ditemukan terkait dengan kualifikasi guru madrasah, seperti: guru yang belum memiliki ijazah Sarjana (S-1), atau memiliki ijazah S-1 tetapi tidak linier dengan bidang studi yang diampu. Padahal dalam Permendiknas No. 16 tahun 2007 Pasal 1 telah menyebutkan, bahwa "setiap guru wajib memenuhi standar kualitas akademik dan kompetensi guru yang berlaku secara nasional." Dalam lampiran Permendiknas tersebut dipaparkan kualifikasi guru mulai tingkat PAUD hingga SLTA harus memenuhi kualifikasi akademik Sarjana 1 (S-1) atau Diploma empat (DIV).

Ada dua kualifikasi akademik guru yaitu kualifikasi guru melalui pendidikan formal dan kualifikasi guru melalui uji kelayakan dan kesetaraan. Dimana hal tersebut dijelaskan dengan kualifikasi akademik yang disyaratkan untuk dapat diangkat sebagai guru dalam bidang-bidang khusus yang sangat diperlukan. Hal tersebut belum dapat dikembangkan di perguruan tinggi, namun dapat diperoleh melalui uji kelayakan dan kesetaraan. Uji kelayakan dan kesetaraan bagi seseorang yang memiliki keahlian tanpa

${ }^{6}$ Imron Fauzi, Etike Profesi Keguruan (Jember: IAIN Press, 2017), 82.

7 PP No. 74 tahun 2008 tentang Guru jo PP No. 19 tahun 2017, Pasal 2. 
ijazah dilakukan oleh perguruan tinggi yang diberi wewenang untuk melaksanakannya. ${ }^{8}$

Masalah linieritas guru merupakan masalah klasik, banyak guru yang tidak cair tunjangan profesi/sertifikasinya gara-gara 'tidak linier'. Oleh karena itu, dengan terbitnya Permendikbud No. 46 Tahun 2016 Tentang Penataan Linieritas Guru Bersertifikat Pendidik, Pada Pasal 1 bahwa, "Linieritas bagi guru merupakan kesesuaian antara sertifikat pendidik dengan mata pelajaran yang diampu oleh guru.”

Selain kualifikasi akademik yang tidak sesuai, guru juga sangat jarang diikutkan pelatihan untuk meningkatkan kemampuannya. Menengok berbagai permasalahan tersebut, maka apakah sesuai jika solusi utama yang ditawarkan adalah sertifikasi? Karena kenyataannya, sertifikasi hanya dianggap sebagai sebuah proses yang harus dilalui untuk mengejar tunjangan yang dijanjikan, bukan sebagai upaya meningkatkan kualifikasi dan kompetensi guru.

Sertifikasi adalah proses pemberian sertifikat pendidik kepada guru yang telah memenuhi persyaratan tertentu, yaitu memiliki kualifikasi akademik, kompetensi, sehat jasmani dan rohani, serta memiliki kemampuan untuk mewujudkan tujuan pendidikan nasional, yang dibarengi dengan peningkatan kesejahteraan yang layak. ${ }^{9}$ Sertifikasi adalah proses pemberian sertifikat pendidik untuk guru dan dosen. Sertifikasi pendidik adalah bukti formal sebagai pengakuan yang diberikan kepada guru dan dosen sebagai tenaga profesional. ${ }^{10}$

Dalam Undang-undang No. 14 Tahun 2005 ditentukan bahwa seorang: (1) Pendidik wajib memiliki kualifikasi akademik dan kompetensi pendidik sebagai agen pembelajaran; (2) Kualifikasi akademik diperoleh melalui pendidikan tinggi program sarjana (S1) atau program diploma empat (D-IV) yang sesuai dengan tugasnya sebagai guru untuk guru dan S-2 untuk dosen; dan (3) Kompetensi profesi pendidik meliputi kompetensi pedagogik, kompetensi kepribadian, kompetensi profesional, dan kompetensi sosial.

\footnotetext{
8 Yaya Jakaria, Analisis Kelayakan dan Kesesuaian Antara Latar Belakang Pendidikan Guru dengan Mata Pelajaran Yang Diampu (Jakarta: Kementerian Pendidikan Nasional, 2014), 504.

${ }_{9}^{9}$ Masnur Muslich, Sertifikasi Guru Menuju Profesionalisme Pendidik (Jakarta: Bumi Aksara, 2007), 2

10 Undang-undang Nomor 14 Tahun 2005, Pasal 1.

44 | Tarbiyatuna: Jurnal Pendidikan Islam; Volume 12, Nomor 1, Februari 2019 p-ISSN: 2085-6539, e-ISSN: 2242-4579
} 
Guru yang layak menerima tunjangan sebagai upaya perbaikan nasibnya agar profesi yang dijalaninya selama ini 'diakui' sebagai profesi dan 'disamakan' dengan profesi-profesi lainnya yang dianggap layak sebagai profesi. Guru benar-benar sebagai sosok yang siap untuk digugu dan ditiru, siap memenuhi panggilan tugas dan kewajiban dengan segala tanggung jawabnya, kemudian siap menerima tunjangan sebagai konsekuensi dari sebuah profesionalitas.

Namun, realitasnya program sertifikasi guru ternyata tidak memberi dampak perbaikan terhadap mutu pendidikan nasional yang cukup signifikan. Padahal, penyelenggaraannya telah menguras sekitar dua pertiga dari total anggaran pendidikan yang mencapai 20 persen APBN. Kesimpulan Bank Dunia itu diperoleh setelah meneliti sejak 2012 di 120 SMP di seluruh Indonesia, dengan melibatkan 39.531 siswa. Hasil tes antara siswa yang diajar guru yang bersertifikasi dan yang tidak, untuk mata pelajaran Matematika, bahasa Indonesia, serta IPA dan bahasa Inggris diperbandingkan. Hasilnya, tidak terdapat pengaruh program sertifikasi guru terhadap hasil belajar siswa SMP. Program sertifikasi guru sesungguhnya tuntutan yang diamanatkan UU Nomor 14 Tahun 2005 tentang Guru dan Dosen, yang mewajibkan seluruh guru disertifikasi dan diharapkan tuntas sebelum 2015. Upaya ini sematamata dimaksudkan untuk meningkatkan kemampuan profesional guru, yang selanjutnya akan berdampak pada peningkatan mutu pendidikan nasional secara keseluruhan. Sejak 2005, guru-guru telah diseleksi untuk mengikuti program sertifikasi berdasarkan kualifikasi akademik, senioritas, dan golongan kepangkatan, seperti harus berpendidikan S-1 dan jumlah jam mengajar 24 jam per minggu. Indikator ini digunakan untuk memperhatikan kompetensi pedagogis, kepribadian, sosial, dan emosional mereka. Lebih dari 2 (dua) juta guru telah disertifikasi, baik melalui penilaian portofolio pengalaman kerja dan pelatihan yang telah diperoleh ataupun melalui pendidikan dan latihan profesi guru (PLPG) selama 90 jam. Para guru yang telah lulus disebut guru bersertifikasi dan berhak mendapatkan tunjangan profesi sebesar gaji pokok yang diterima setiap bulannya. ${ }^{11}$

11 Dwi Rahmawati, Hubungan antara Motivasi Berpestasi dan Persepsi Kepemimpinan Kepala Sekolah dengan Kinerja Guru (Studi pada Penerima Tunjangan Sertifikasi Guru), dalam eprints.ums.ac.id, diakses pada tanggal 24 Oktober 2018. 
Penelitian lain juga dilakukan oleh Prof. Baedhowi di Jawa Tengah dan Jawa Timur menunjukkan bahwa guru yang telah mengikuti sertifikasi tidak mengalami peningkatan kompetensi, menyebutkan bahwa 50\% dari 3.670 responden menyatakan guru yang telah sertifikasi tidak mengalami peningkatan kompetensi pedagogik, kompetensi kepribadian, kompetensi profesional, maupun kompetensi sosialnya. Disebutkan pula hampir semua guru menyatakan bahwa motivasi utama mengikuti sertifikasi adalah terkait masalah finansial. ${ }^{12}$

\section{Konsep Mutasi Guru}

Mutasi ini bagian dari fungsi operasional dari manajemen sumber daya guru, yakni keseluruhan proses pengelolaan terhadap para guru sehingga dapat memiliki kualifikasi dan kompetensi yang sesuai dengan tuntutan dan kebutuhan kerja mereka secara profesional, yang meliputi: perencanaan kebutuhan, rekrutmen dan seleksi, pembinaan dan pengembangan, mutasi dan promosi, serta kesejahteraan. ${ }^{13}$

Kegiatan mutasi guru ini dilakukan untuk melaksanakan prinsip menempatkan guru yang tepat pada tempat yang tepat. Mutasi didasarkan pada beberapa alasan yaitu kemampuan kerja, rasa tanggung jawab, dan kepuasan. Diharapkan dengan mutasi guru melaksanakan pekerjaan dengan efektif, efisien, dan dapat meningkatkan kinerjanya. Meskipun demikian, harus diperhatikan bahwa guru dapat salah persepsi

12 Baedhowi, 2009, Tantangan Profesionalisme Guru pada Era Sertifikasi. Naskah Pidato Pengukuhan Guru Besar UNS, tanggal 12 November 2009.

13 Para pakar berbeda pendapat dalam menafsirkan dan menggunakan istilah setiap fungsi Manajemen Sumber Daya Manusia ini, misalnya Simamora (1999:3) meliputi: pendayagunaan, pengembangan, penilaian, pemberian balas jasa, dan pengelolaan individu atau kelompok pekerja. Handoko (2008:4) meliputi: penarikan, seleksi, pengembangan, pemeliharaan, dan penggunaan sumber daya manusia. Mangkunegara (2002:2) meliputi: pengadaan, pengembangan, pemberian balas jasa, pengintegrasian, pemeliharaan dan pemisahan tenaga kerja. Sofyandi (2009:6) meliputi: proses penarikan, seleksi, pelatihan dan pengembangan, penempatan yang terdiri dari promosi, demosi dan transfer, penilaian kinerja, pemberian kompensasi, hubungan industrial, hingga pemutusan hubungan kerja. Flippo (1984:5) meliputi: pengadaan tenaga kerja, penegembangan, kompensasi, integrasi, pemeliharaan, dan pemutusan hubungan kerja dengan sumber daya. Gomes (2003:6) meliputi: pengadaan, pengembangan, pemberian kompensasi, pengintegrasian, pemeliharaan dan pemutusan hubungan tenaga kerja. Gary Dessler (1997) meliputi: perekrutan, penyaringan, pelatihan, pemberian imbalan, dan penilaian. Sadili (2010) meliputi: perencanaan sumber daya manusia, rekrutmen, seleksi, pelatihan dan pengembangan, penilaian prestasi kerja, kompensasi, pemeliharaan keselamatan tenaga kerja, dan hubungan karyawan. Khusnuridlo (2013) meliputi: perencanaan kebutuhan, rekrutmen dan seleksi, pembinaan dan pengembangan, mutasi dan promosi, serta kesejahteraan. Meskipun berbeda dalam membagi fungsi/tahapan dan istilah yang digunakan, namun pada hakikatnya sama. 
yang berasumsi bahwa mutasi sebagai hukuman. Hal tersebut dapat berakibat menurunnya efektifitas, efisiensi, dan kinerja pegawai. ${ }^{14}$

Gagasan penyelenggaraan mutasi tidak selamanya berasal atas kebijakan manajemen kelembagaan saja, tetapi seringkali berasal dari keinginan guru sendiri. Oleh karena itu, mutasi dapat dibedakan menjadi dua sumber, yaitu: mutasi atas keinginan guru dan mutasi atas kebijakan manajemen kelembagaan yang diambil dan ditujukan pada hal-hal yang positif.

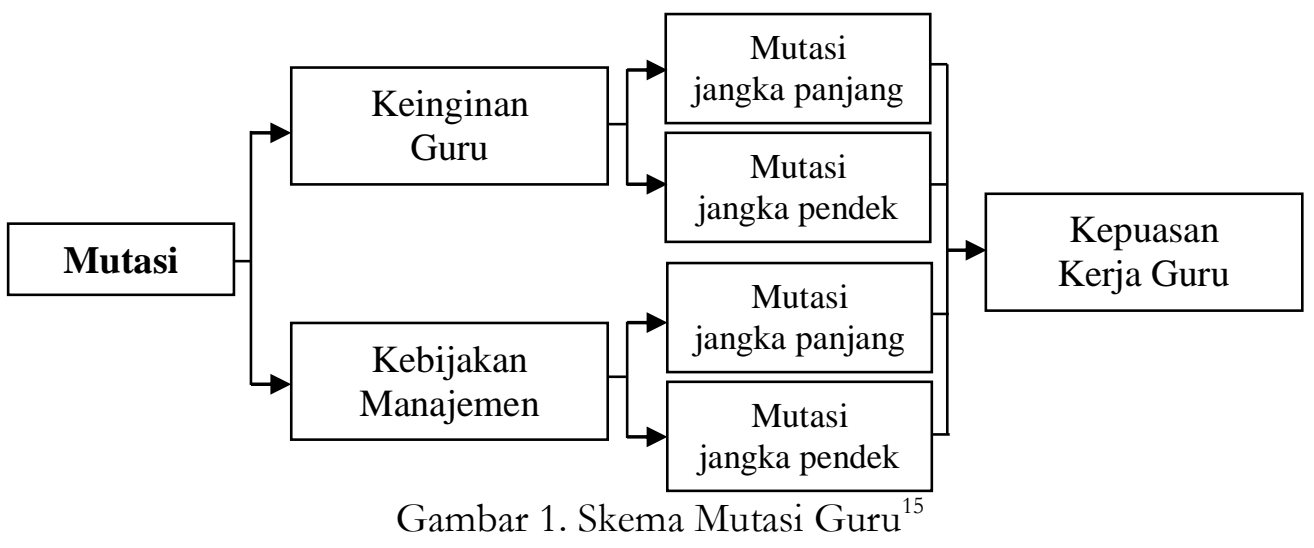

Oleh karena itu, Bambang Wahyudi memberikan persyaratan diberlakukannya mutasi tersebut, diantaranya:

1. Setiap mutasi yang dilakukan hendaknya jangan sampai dirasakan sebagai suatu hukuman bagi guru yang bersangkutan. Oleh karena itu, hendaknya lembaga melakukan konsultasi terlebih dahulu dengan guru yang bersangkutan sebelum mutasi dilaksanakan. Hal tersebut penting untuk meyakinkan bahwa pemindahan merupakan sesuatu yang bersifat rutin, wajar atau biasa dalam berorganisasi, serta ditujukan semata-mata demi kepentingan bersama.

2. Hendaknya mutasi dilakukan untuk memperkuat kerjasama kelompok. Untuk itu, suatu organisasi harus sungguh-sungguh mempertimbangkan dan melakukan seleksi dengan ketat setiap tenaga kerja yang dipindahkan apabila setelah pelaksanaan mutasi personal ternyata justru menimbulkan konflik, maka jelas mutasi tersebut mengalami kegagalan.

14 A. S. Nitisemito, Manajemen Personalia (Jakarta: Ghalia Indonesia, 1996), 71.

15 Moh. Khusnuridlo, Standar Nasional Pendidikan: Manajemen Sumber Daya Pendidik dan Kependidikan (Jember: STAIN Jember Press, 2013), 195. 
3. Mengurangi kejenuhan dari seorang guru. Seorang guru yang secara terusmenerus barada dalam satu jabatan dapat menimbulkan kejenuhan/kebosanan terhadap tugas jabatannya. Adanya mutasi diharapkan mampu menjadi jalan keluar dari suasana tersebut. ${ }^{16}$

\section{Kebijakan Mutasi Guru di Kabupaten Jember}

\section{Problematika Mutasi Guru PNS}

Dalam upaya merealisasikan 22 Janji Bupati Jember, ${ }^{17}$ khususnya pada point ke-16, Pemerintah Kabupaten mengeluarkan kebijakan tentang mutasi guru secara besar-besaran yang dimulai pada akhir 2017 lalu. Mutasi tahap awal yang dilakukan berdasarkan permohonan para guru Pegawai Negeri Sipil (PNS) untuk dimutasi ke sekolah yang berdekatan dengan lokasi rumah mereka. Dari sekitar seribu orang guru PNS yang permintaan mutasinya diakomodasi oleh Bupati. Semua yang mengajar (di sekolah dengan jarak dari rumah) lebih dari 25 kilometer langsung diizinkan untuk pindah.

${ }^{16}$ Bambang Wahyudi, Manajemen Sumber Daya Manusia (Bandung: Penerbit Sulita, 1996), 181.

1722 Janji kerja Bupati Jember itu yaitu: (1) sekolah gratis hingga tingkat SMA/SMK; (2) memberikan 5000 beasiswa Perguruan Tinggi bagi siswa berprestasi; (3) meningkatkan mutu Pendidikan Diniyah, Madrasah dan Pondok Pesantren, serta memperkuat jaringan masjid dan pondok pesantren sebagai pusat informasi dan Pendidikan publik; (4) meningkatkan sebesar 3 kali lipat honor guru mengaji dan meningkatkan bantuan untuk guru PAUD; (5) menjadikan Jember sebagai pusat embarkasi Haji wilayah Timur Indonesia; (6) memberikan asuransi kesehatan bagi para khotib dan guru mengaji; (7) meningkatkan kualitas infrastruktur dengan melakukan pengaspalan jalan hingga ke pelosok, membangun dan memperbaiki jembatan, drainase, dan irigasi; (8) mengembangkan warung berjaringan, merevitalisasi pasar tradisional dan menata pedagang kaki lima untuk meningkatkan pendapatan para pedagang dan meningkatkan kesejahteraan keluarga mereka; (9) memberikan bantuan modal usaha, teknologi dan pemasaran untuk petani, peternak, nelayan, UMKM, dan koperasi; (10) membangun kedaulatan pangan melalui penyediaan pengairan, penyediaan pupuk tepat waktu, dan optimalisasi lahan pertanian; (11) menata dan merevitalisasi industri tembakau dengan meningkatkan produktivitas sektor ini untuk meningkatkan kesejahteraan petani dan buruh tembakau; (12) meningkatkan potensi sumberdaya kelautan dan meningkatkan perlindungan bagi masyarakat pesisir antara lain dengan memberikan asuransi kerja untuk para nelayan; (13) memberikan layanan kesehatan gratis dan melakukan operasi gratis bagi Dhuafa; (14) membangun dan merevitalisasi berbagai fasilitas dan pusat layanan kesehatan yang mendekat ke masyarakat, antara lain: merevitalisasi puskesmas, menyediakan 3 dokter di setiap pukesmas, dan ambulans di setiap desa; (15) membangun layanan usaha dan layanan publik satu pintu yang transparan dan efisien untuk mendorong laju perekonomian dan investasi daerah dan memperluas lapangan kerja; (16) mereformasi birokrasi untuk mempermudah dan mempercepat layanan-layanan bagi warga, membangun sistem anti korupsi, dan meningkatkan kesejahteraan pegawai honorer dan PNS; (17) memperkuat kelembagaan desa dalam rangka meningkatkan keterlibatan dan kesejahteraan masyarakat desa, antara lain melalui program satu desa satu dosen, mencairkan dana desa secara tepat waktu, dan menyegarkan pelakanaan UU Desa dengan menerbitkan Perda dan Perbup; (18) meningkatkan bantuan honor ketua RT/RW; (19) mengembangkan industri kreatif dan pariwisata untuk menjadikan Jember sebagai salah satu kota wisata utama; (20) merintis dan mengembangkan bandara Jember menjadi bandara komersial; (21) mengembangkan kegiatan olahraga, kesenian, kebudayaan, kepemudaan, berbasis taman-taman public; (22) menjadikan Jember sebagai Bumi Shalawat yang ramah lingkungan, ramah warga berkebutuhan khusus, ramah Ibu dan anak, serta ramah kelompok minoritas. lihat https://jemberkab.go.id/ 
Bupati Jember menjelaskan bahwa, mutasi guru PNS itu atas permohonan dari guru yang bersangkutan. Dari 316 guru pemohon mutasi, di antaranya 252 PNS guru SDN dan 64 PNS guru SMPN. Sesuai data yang ada, guru di Jember tercatat 6.976 PNS. Jika dibandingkan dengan total jumlah keseluruhan, maka permohonan mutasi 316 guru tersebut prosentase perbandingannya tidak sampai 5 persen. Dari 316 guru yang dimutasi, 258 orang sesuai permohonan, 30 orang sesuai dalam satu desa/kelurahan, 5 orang lain desa sesuai kecamatan dan 23 orang lain kecamatan terdekat. ${ }^{18}$

Pada tanggal 16 Maret 2018, Bupati Jember, Faida, menyerahkan surat keputusan mutasi kepada ratusan guru PNS. Penyerahan dilakukan secara langsung di Aula PB. Soedirman Pemkab Jember. Guru yang berstatus PNS tersebut mendapatkan kesempatan dalam menjalani proses mutasi. Faida menjelaskan, dengan dekat dari rumah tinggal dan tempat kerja maka akan terjadi pula peningkatan kesejahteraan para pegawai karena tidak terbebani biaya transportasi, selain mendekatkan diri pada keluarga. ${ }^{19}$

Namun, menurut Ketua PGRI Jember, Supriono mengatakan,

"mutasi tugas guru PNS ke sekolah dekat rumah tidak berdasarkan aturan pemerintah. Semestinya kalau menurut aturan pemerintah, seorang guru PNS, jika hendak dimutasi, harus (menjalani tugas) minimal lima tahun di tempat tugasnya itu. Tetapi para guru PNS ini masih banyak yang hanya satu tahun, dua tahun, atau belum genap lima tahun sudah dimutasi:"20

Menurut penulis, berdasarkan kajian teori tersebut di atas, seharusnya mutasi guru itu lebih didasarkan pada formasi kebutuhan sekolah (bezetting), bukan sekedar didekatkan dengan tempat tinggalnya (zonasi) saja sesuai KTP. Karena jika sekolah yang ditinggalkan tersebut kekurangan guru PNS dan tidak ada penggantinya, maka pelayanan pendidikan pun terganggu. Menurut ketua PGRI Jember, "rata-rata sekolah negeri di Jember, hanya memiliki empat guru PNS, termasuk kepala sekolah. Padahal idealnya sembilan orang guru PNS. Jadi,

\footnotetext{
${ }^{18 h t t p s: / / n e w s . d e t i k . c o m / b e r i t a-j a w a-t i m u r / d-3680633 / r a t u s a n-g u r u-d i-j e m b e r-d i m u t a s i-d i s e s u a i k a n-t e m p a t-~}$ tinggal.

19 https://jemberkab.go.id/bupati-serahkan-sk-mutasi-guru/ .

${ }^{20} \mathrm{http}: / /$ beritajatim.com/pendidikan_kesehatan/322283/bupati_faida_mutasi_seribu_guru_pns_agar_dekat_rum ah.html. 
Kabupaten Jember sangat kekurangan guru PNS, apalagi di daerah-daerah pelosok seperti: Bintoro, Sumberjambe, Sumberbaru, Jelbuk, Arjasa, Tempurejo, Panti, PNS di sana malah ditarik ke sekolah di dekat rumah. Tentunya di sana terjadi kekurangan guru."

Dengan adanya mutasi guru PNS tersebut dari sekolah di pelosok ke sekolah yang lebih dekat dengan rumahnya yang notabene mayoritas di daerah perkotaan, sehingga banyak guru-guru Honorer, GT'T, atau guru Sukwan yang tersingkir begitu saja karena harus ditempati oleh guru PNS, meskipun masa kerja mereka lebih lama ketimbang guru yang PNS itu.

Kebijakan mutasi ratusan guru SD dan SMP di Kabupaten Jember tersebut memang menimbulkan persoalan di sejumlah sekolah. Pasalnya mutasi guru yang dilakukan oleh Bupati Jember itu, berakibat pada sekolah SD dan SMP di pinggiran atau pelosok Kabupaten Jember mengalami kekurangan guru. Bahkan diketahui, ada beberapa sekolah yang guru dan kepala sekolahnya harus merangkap mengajar melebihi jam mengajar, serta diketahui juga ada sekolah yang hanya menyisakan kepala sekolahnya saja tanpa memiliki guru PNS satu pun.

Sehingga menimbulkan ketidak-seimbangan jumlah guru di setiap sekolah. Misalnya, guru di SD A yang dimutasi sebanyak 8 orang, sedangkan guru yang masuk ke SD A hanya 3 orang. Sehingga kekurangan 5 guru. Secara otomatis harus sekolah tersebut harus merekrut guru baru lagi, dan itu membutuhkan waktu yang tak sebentar. Dan pastinya yang menjadi korban adalah peserta didiknya. Contoh, di SDN 4 Suci Kecamatan Panti hingga sekarang mengalami kekurangan guru, akibat mutasi yang dilakukan oleh Bupati Jember beberapa waktu lalu. Kepala SDN 4 Suci mengatakan, "sebelum adanya mutasi, guru disini sudah lengkap, kita mendapatkan tambahan guru K2 berjumlah tiga orang. Tapi baru satu tahun mengajar, tiba-tiba dua orang guru di mutasi. Tidak tahu proses mutasinya kapan, tiba-tiba mereka pamitan mau 
pindah." ${ }^{21}$ Lebih parah lagi, di SDN Bintoro 5 Patrang yang hanya tersisa 1 (satu) PNS saja, yakni Kepala Sekolahnya.

Jadi, kebijakan Bupati Jember untuk memutasi sejumlah guru PNS agar dekat dengan rumahnya justru berdampak terhadap terganggunya proses pembelajaran di sekolah. Pasalnya, akibat kebijakan tersebut sejumlah sekolah mengalami kekurangan guru PNS. Kebijakan mutasi itu memang merupakan kewenangan Bupati selaku Pembina PNS. Hanya saja, untuk mutasi guru PNS, semestinya mempertimbangkan kebutuhan kondisi masing-masing sekolah. Sebab, di sejumlah sekolah justru mengalami kekurangan guru PNS pasca mutasi tersebut, di sisi lain ada sekolah yang mengalami kelebihan guru.

Kebijakan mutasi tersebut juga berdampak pada kesejahteraan guru yang telah sertifikasi. Sebab, bagi para guru yang jam mengajarnya kurang, maka mereka malah terancam tidak dapat mencairkan tunjangan sertifikasinya.

2. Problematika Mutasi Guru Tidak Tetap (GTT)

Bupati Jember memaparkan, ada sekitar 5.001 GT'T yang terdata oleh tim verifikasi Dinas Pendidikan Kabupaten Jember. Dari jumlah tersebut, 3.325 guru yang diajukan untuk mendapatkan surat penugasan pada tahun 2017. Untuk sisanya sebanyak 1.676 yang belum diajukan dan rencananya bakal diusulkan mendapat surat penugasan di tahun 2018 ini. $^{22}$

Pada bulan April 2018 lalu, Bupati Jember memutasi Guru Tidak Tetap (GTT) secara besar-besaran dengan alasan supaya lebih linier antara kualifikasi dan tugas yang diampunya, serta disesuaikan dengan zonasi tempat tinggalnya berdasarkan Kartu Tanda Penduduk (KTP). Namun realitanya, Kebijakan Bupati Jember memutasi sejumlah GTT tersebut menuai kontroversi. Beberapa penolakan tersebut diantaranya karena:

Pertama, banyak GTT yang malah dimutasi lebih jauh dari domisilinya, misalnya: guru A memiliki ijazah S1 Pendidikan Bahasa Inggris, yang sebelumnya dia menjadi guru kelas di SD A di daerah Tanggul yang dekat dengan rumahnya.

\footnotetext{
21 http:/ /arsip.suaraindonesia.co.id/read/1975/20171019/192913/garagara-mutasi-tidak-sesuai-sejumlahsekolah-di-jember-kekurangan-guru/.

22 http://jembergo.id/soal-gtt-ptt-segera-dituntaskan-bupati-faida/. 
Kemudian, supaya linier akhirnya dia dimutasi menjadi guru Bahasa Inggris di salah satu SMP di daerah Silo. Kasus seperti itu banyak dialami oleh GTT mutasi tersebut, sehingga dengan jarak yang terlalu jauh itu malah akan menghambat kelancaran dalam melaksanakan tugas mengajar, bahkan menurut data yang penulis peroleh, bahwa selama 5 (lima) bulan terakhir ini terdapat 3 (tiga) GTT mutasian itu yang meninggal dan 1 (satu) yang patah tulang, karena kecelakaan ketika berangkat mengajar. ${ }^{23}$

Kedua, adanya kesenjangan antara proses mutasi guru PNS dengan GTT. Proses mutasi guru PNS didasarkan pada permohonan guru yang bersangkutan untuk didekatkan dengan tempat tinggal tanpa melihat kebutuhan sekolahnya, atau dengan kata lain, guru PNS ditawari terlebih dahulu sebelum dimutasi. Sedangkan, GT'T dimutasi hanya berdasarkan verifikasi data yang dilakukan tim Dinas Pendidikan yang notabene hanya berdasarkan KTP, bukan usulan atau permohonan. Sehingga menimbulkan kecemburuan para GTT tersebut yang dapat berdampak pada keterpaksanaan dalam melaksanakan tugas mengajarnya, bahkan penolakan.

Sebagaimana yang dialami oleh Nur Fadli, salah seorang GTT, sekaligus tokoh pendiri lembaga-lembaga pendidikan di pelosok, yang terang-terangan menolak keputusan Bupati Jember, atas mutasi dirinya dari tempat asal ke sekolah baru. Meskipun Fadli sendiri dipindah dari SDN Bintoro 5 ke SMP 1 Sokorambi yang notabene lebih dekat dengan rumahnya, namun hal itu malah tidak membuatnya senang, karena SDN Bintoro 5 merupakan lembaga hasil rintisan dan perjuangannya. ${ }^{24}$

Ketiga, sulitnya adaptasi diantara para guru dan peserta didik. Dengan adanya mutasi besar-besaran dan serentak tersebut membuat para GTT dan peserta didik terkejut dan harus beradaptasi dengan kondisi yang berbeda. Hal itu mempengaruhi kualitas pembelajaran yang dilakukan. Sang guru yang merasa nyaman dan telah memiliki ikatan emosional dengan peserta didik lamanya tiba-

\footnotetext{
23 Wawancara dengan GTT di SDN Silo 02 dan GTT di SDN Suci 01 Panti.

24 http://www.memoonline.co.id/read/1535/20180518/162310/jember-bergolak-kebijakan-bupati-memutasigtt-menuai-kontroversi/.

52 | Tarbiyatuna: Jurnal Pendidikan Islam; Volume 12, Nomor 1, Februari 2019 p-ISSN: 2085-6539, e-ISSN: 2242-4579
} 
tiba harus dipisahkan, dan harus berpindah di tempat yang mayoritas belum mereka ketahui sebelumnya. Begitu pula yang dirasakan oleh peserta didiknya. Padahal kenyamanan dan kenikmatan dalam mengajar itulah menjadi salah satu penentu kualitas pembelajaran itu sendiri.

Keempat, permasalahan terkait Surat Penugasan (SP) GTT. Realisasi pemberian SP ternyata tidak terlaksana sesuai dengan rencana awal terkait mutasi guru itu sendiri, yakni meningkatkan kesejahteraan GTT dengan adanya linierisasi sehingga akan mempermudah proses sertifikasi guru. Namun malah sebaliknya, SP itu tidak dapat dipergunakan untuk keperluan sertifikasi tersebut. Menurut beberapa GTT yang penulis temui, meskipun telah mengikuti Sistem Informasi Manajemen Pengembangan Keprofesian Berkelanjutan (SIM-PKB) dan lulus Pre-test, tetapi mereka tidak bisa mengikuti tahap Pendidikan Profesi Guru (PPG), karena yang dimiliki hanya SP, bukan SK Pengangkatan. Sedangkan salah satu syarat sertifikasi tersebut yang dibutuhkan adalah SK Pengangkatan. ${ }^{25}$

Selain itu, pemberian SP di Kabupaten Jember pun terkesan carut marut. Karena masih banyak GTT yang mengabdi di atas 10 tahun dan memiliki ijazah linier, malah tidak tercover. Sementara ada GTT yang belum berijazah S1 (lulusan D2), dan banyak juga pengabdian hanya dibawah 5 tahun, namun mereka mendapatkan SP. Dan anehnya, dalam surat penugasan tersebut dicantumkan sudah lulus $\mathrm{S} 1 .^{26}$

Kelima, ketidaksesuaian antara honor dan jaminan yang tertera di dalam SP dengan realisasinya. Redaksi atau isi SP tersebut setiap guru tidak sama, disesuaikan dengan masa kerja dan zonasi tempat tinggal dan sekolah. Jumlah gaji pun disesuaikan dengan masa kerja (kurang dari 5 tahun; 5-9 tahun; 9-15 tahun; dan lebih 15 tahun); dan ditambah tunjangan sesuai zonasi tersebut. Contohnya, di dalam SP tersebut tertulis masa kerja lebih 15 tahun, dan mendapat gaji sebesar Rp. 900.000,- dan ditambah dengan tunjangan dari BOSDA sesuai dengan zonasinya. Padahal gaji mereka berasal dari BOS sebesar 15\%. Misal, di SD A itu

\footnotetext{
25 Wawancara dengan GTT di SDN Slawu 1 Patrang dan GTT di SDN Baratan 2 Patrang.

26 http:/ /www.memoonline.co.id/read/1535/20180518/162310/jember-bergolak-kebijakan-bupati-memutasigtt-menuai-kontroversi/. 
mendapat BOS sebesar 60 juta/tahun, maka 15\%-nya adalah Rp. 9 juta. Jika GTT disana terdapat 4 orang, maka gaji setiap GTT itu sebesar Rp. 2.250.000,/tahun atau hanya Rp. 187.500,-/bulan. Nah, padahal tertulis dalam SP sebesar Rp. 900.000,- namun mereka hanya mendapatkan Rp. 187.500,- Sedangkan, tunjangan tambahan dari BOSDA Program Pendidikan Gratis (PPG) Kabupaten Jember yang berikan pun masih tidak merata, tidak jelas ukuran atau indikator perhitungannya, dan sering terhutang. ${ }^{27}$ Realita tersebut jauh di bawah UMR Kabupaten Jember tahun 2018 yakni sebesar Rp. 1.916.983,--

Keenam, kesalahan data mutasi guru dan penentuan tugas mengajar. Masih terdapat sebagaian pemetaan mutasi guru yang tidak sesuai domisili. Karena acuan yang dipergunakan dalam pemetaan tersebut hanyalah KTP, tetapi tidak semua guru tinggal sesuai dengan KTP-nya, diantaranya karena nikah di lain daerah, membeli rumah di lain daerah, atau sebab lain, sehingga tempat tugas baru ini banyak yang malah lebih jauh dan sulit dijangkau dari tempat tinggal asalanya. Selain itu, ada pula kesalahan dalam menentukan tugas mengajar. GTT yang awalnya sudah linier antara kualifikasi dan tugas mengajarnya malah dimutasikan dengan tugas yang tidak linier. Misalnya, ijazah S1 PGSD yang awalnya memang menjadi Guru Kelas di SD (sudah linier), di mutasi menjadi guru Pendidikan Olahraga atau Mata Pelajaran lain di sekolah lain (malah tidak linier).

\section{Alternatif Solusi}

Meskipun implementasi kebijakan terkait linierisasi dan mutasi guru di Kabupaten Jember, baik guru PNS maupun Guru Tidak Tetap (GTT), mengalami banyak problematika, namun harus tetap berusaha untuk mencari alternatif Win-win Solution demi kepentingan bersama dan kemajuan pendidikan. Karena itu, penulis menawarkan beberapa solusi.

Secara operasional, solusinya yaitu: (a) Pemerintah Kabupaten Jember hendaknya melakukan pemetaan ulang berdasarkan analisis kebutuhan sekolah sesuai dengan realita di lapangan, bukan analisis domisili saja, dengan melibatkan

27 Wawancara dengan GTT di SDN Gebang 03 Patrang dan SDN Tembokrejo 04 Gumukmas.

54 | Tarbiyatuna: Jurnal Pendidikan Islam; Volume 12, Nomor 1, Februari 2019 p-ISSN: 2085-6539, e-ISSN: 2242-4579 
para pengawas kecamatan dan setiap kepala sekolah; (b) Pemerintah Kabupaten Jember hendaknya melibatkan para guru (baik PNS dan GTT) melalui Citizen's Charter (kontrak layanan) dalam setiap pengambilan keputusan atau kebijakan yang dilakukan; (c) Pemerintah Kabupaten Jember hendaknya melakukan sosialisasi persuasif sebelum kebijakan tersebut diimplementasikan, supaya sasaran kebijakan (guru) tidak merasa kaget dan memberontak; dan (d) Percayakan dan berdayakan unit-unit di bawah Bupati, mulai dari Dinas Pendidikan hingga pengawas di setiap kecamatan, sesuai dengan tugas dan fungsinya masing-masing.

Secara substansial, solusinya adalah penciptaan good goverment, karena jika sistem birokrasi pemerintah baik, maka pelayanan pendidikan pun akan baik, diantaranya yaitu:

a. Reformasi birokrasi dan rotasi jabatan pada OPD di Kabupaten Jember boleh-boleh saja, asal tidak asal-asalan dan hindari unsur like and dislike. Karena mismatch yang terjadi selama ini terlalu besar, terutama di beberapa pemerintah daerah. Ini bisa terjadi, akibat adanya like and dislike. Misalnya, sarjana hukum menjadi kepala PU, sarjana pendidikan menjadi Kepala Dinas Kesehatan, dan sebagainya. Selain itu, sebaiknya tidak tergesa-gesa melakukan rotasi pejabat di Dinas Pendidikan Kabupaten Jember sehingga akan menghambat kinerja para bawahannya dan akan berdampak negatif hingga level pelaksana paling bawah yakni sekolah dan guru. Misalnya, pada tanggal 8 Oktober 2018 lalu Bupati Jember memutasi Kepala Dinas Pendidikan, Isman Sutomo, menjadi Staf Ahli Bidang Pembangunan, Perekonomian, dan Keuangan Kabupaten Jember. Padahal masa jabatannya menjadi Kepala Dinas Pendidikan terhitung cepat, hanya 57 hari, terhitung dari pelantikan tanggal 13 Agustus 2018. Dan diganti oleh Mohammad Ghozali sebagai Plt. Artinya, ketika kepala dinas sering diganti oleh Plt, bukan kepala dinas secara definitif, maka akan menghambat segala proses strategis yang ada di dalam dinas tersebut bahkan hingga proses operasional di sekolah pun akan terkendala. 
b. Menanggapi Peraturan Menteri Dalam Negeri Nomor 12 Tahun 2017, Pemerintah Kabupaten Jember menghapus dan membubarkan seluruh UPT Dinas Pendidikan di 31 Kecamatan secara serentak dan mendadak, sehingga mengakibatkan terhambatnya pelayanan pendidikan di setiap kecamatan. Lalu pertanyaannya adalah: Bagaimana fungsi koordinasi antar pengawas sekolah di setiap kecamatan tersebut? Bagaimana nasib Pegawai Tidak Tetap (PTT) di setiap UPT tersebut? Dan untuk apa menumpuk aset UPT Dinas Pendidikan, serta membiarkan gedung bekas UPT tersebut? Beberapa pertanyaan itu yang harus segera dijawab dan ditindak-lanjuti supaya pelayanan pendidikan, khususnya terkait dengan guru, dapat berjalan dengan maksimal.

c. Hilangkan ego-sektoral dan tumbuhkan belief system di tubuh birokrasi pemerintah Kabupaten Jember. Sebenarnya pemerintah pusat telah serius dan menggebu dalam memajukan pendidikan mulai dari relugasi hingga menyediakan anggaran, namun implementasi pada tingkat pemerintah kabupaten kurang berjalan dengan baik. Hal itu lebih disebabkan karena pemerintah pusat dan pemerintah kabupaten, dan atau antar birokrat di dalam pemerintah Kabupaten Jember itu sendiri masih kurang memiliki belief system yang sama, dan kurangnya koordinasi antara Bupati dan para bawahannya pada OPD yang dipimpinnya, serta pada antar birokrat pada masing-masing OPD tersebut. Ketidak-percayaan pemimpin kepada para bawahannya ini dapat menimbulkan pola kepemimpinan otoriter dan pengambil-alihan tugas yang seharusnya dilaksanakan oleh bawahannya. Koordinasi yang kurang baik di internal Pemerintah Kabupaten dan OPD ini sebagai akibat adanya ego sektoral dan kurangnya belief system.

\section{Kesimpulan}

Implementasi kebijakan mutasi guru dalam rangka me-linier-kan para guru yang dilakukan oleh Pemerintah Kabupaten Jember, masih menuai banyak kendala dan tantangan, diantaranya: (1) mutasi guru tidak didasarkan pada formasi kebutuhan sekolah (bezetting), namun hanya didasarkan tempat tinggalnya (zonasi) saja sesuai KTP, sehingga menimbulkan ketidak-seimbangnya jumlah guru di setiap sekolah; (2) 
banyak GTT yang malah dimutasi lebih jauh dari domisilinya; (3) adanya kesenjangan atau ketidakadilan antara proses mutasi guru PNS dengan GT'T; (4) sulitnya adaptasi diantara para guru dengan peserta didik pada tempat mutasi atau lembaga baru; (5) realisasi pemberian Surat Penugasan (SP) GT'T ternyata tidak terlaksana sesuai dengan rencana awal; dan (6) adanya kesalahan data mutasi guru dan penentuan tugas mengajar.

Oleh karena itu, penulis menawarkan beberapa solusi untuk mengatasi carut marutnya permasalahan mutasi guru tersebut, yakni pemerintah Kabupaten Jember hendaknya melakukan pemetaan ulang berdasarkan analisis kebutuhan sekolah; melibatkan para guru (baik PNS dan GT'T) melalui Citizen's Charter (kontrak layanan) dalam setiap pengambilan keputusan atau kebijakan yang dilakukan; melakukan sosialisasi persuasif sebelum kebijakan diimplementasikan; dan berdayakan unit-unit di bawah Bupati, mulai dari Dinas Pendidikan hingga pengawas di setiap kecamatan, sesuai dengan tugas dan fungsinya masing-masing.

\section{Referensi}

Abas, Haffid. 2010. Kinerja Guru Bersertifikat Belum Memuaskan, dalam Kompas Edisi 6 Oktober

Baedhowi. 2009. Tantangan Profesionalisme Guru pada Era Sertifikasi. Naskah Pidato Pengukuhan Guru Besar UNS, tanggal 12 November.

Dye, Thomas. 1981. Understanding Public Policy, McHill: New York.

Fauzi, Imron. 2017. Etika Profesi Keguruan, Jember: IAIN Press.

http:/ / arsip.suaraindonesia.co.id/read/1975/20171019/192913/garagara-mutasitidak-sesuai-sejumlah-sekolah-di-jember-kekurangan-guru/, diakses pada 25 Oktober 2018

http://beritajatim.com/pendidikan_kesehatan/322283/bupati_faida_mutasi_seribu_ guru_pns_agar_dekat_rumah.html, diakses pada 25 Oktober 2018

http://data.go.id/dataset/guru-sertifikasi, diakses pada 25 Oktober 2018

http://jembergo.id/soal-gtt-ptt-segera-dituntaskan-bupati-faida/, diakses pada 25 Oktober 2018

http://www.memoonline.co.id/read/1535/20180518/162310/jember-bergolakkebijakan-bupati-memutasi-gtt-menuai-kontroversi/, diakses pada 25 Oktober 2018 
http://www.memoonline.co.id/read/1535/20180518/162310/jember-bergolakkebijakan-bupati-memutasi-gtt-menuai-kontroversi/, diakses pada 25 Oktober 2018

http://jemberkab.go.id/bupati-serahkan-sk-mutasi-guru/, diakses pada 25 Oktober 2018

http://news.detik.com/berita-jawa-timur/d-3680633/ratusan-guru-di-jember-

dimutasi-disesuaikan-tempat-tinggal, diakses pada 25 Oktober 2018

Jakaria, Yaya. 2014. Analisis Kelayakan dan Kesesuaian Antara Latar Belakang Pendidikan Guru dengan Mata Pelajaran Yang Diampu, Jakarta: Kementerian Pendidikan Nasional.

Khusnuridlo, Moh. 2013. Standar Nasional Pendidikan: Manajemen Sumber Daya Pendidik dan Kependidikan, Jember: STAIN Jember Press.

Mulyasa, E. 2011. Menjadi Guru yang Profesional: Menciptakan Pembelajaran yang Kreatif dan Menyenangkan. Bandung: PT. Remaja Rosdakarya Offset.

Muslich, Masnur. 2007. Sertifikasi Guru Menuju Profesionalisme Pendidik. Jakarta: Bumi Aksara.

Nitisemito, A.S. 2006. Manajemen Personalia, Jakarta: Ghalia Indonesia.

Peraturan Pemerintah No. 74 tahun 2008 tentang Guru jo PP No. 19 tahun 2017

Rahmawati, Dwi. 2018. Hubungan antara Motivasi Berpestasi dan Persepsi Kepemimpinan Kepala Sekolah dengan Kinerja Guru (Studi pada Penerima Tunjangan Sertifikasi Guru), dalam eprints.ums.ac.id, diakses pada tanggal 24 Oktober.

Ruky, Ahmad S. 2002. Sistem Manajemen Kinerja, Jakarta: Gramedia Pustaka.

Undang-undang Nomor 14 Tahun 2005 tentang Guru dan Dosen

Wahyudi, Bambang. 1996. Manajemen Sumber Daya Manusia, Bandung: Penerbit Sulita. 